\title{
Editorial
}

\section{Research and Writing}

Over the past six months, CERL editorial board members have joined others in a series of programs designed to consider the future of research as a component of the work we do together as members of the Association of College \& Research Libraries. In addition to inviting our readers to reflect

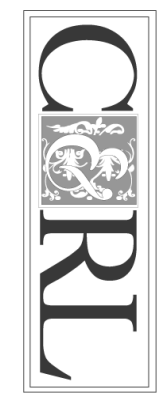
on the enduring value of "landmark" studies from the journal's history in our 75th anniversary issue published in March, we have hosted discussions at the ACRL Conference in Portland and through the CERL online forum series. Participants in these discussions have raised a number of critical questions relevant to the future of both ACRL research programs and ACRL publication programs, some of which complement questions raised in this column over the past year, including the need for a platform publication for academic libraries and the need to support a greater diversity in the research studies published in this journal.

Other questions raised in these discussions have related to the Association's role in promoting the development of research skills among our members, and how ACRL might provide leadership at the national level for developing a continuing professional education program in research skills and evidence-based librarianship that takes a lifelong learning approach to this perennial concern. Some of those participating in these discussions through Twitter (\#acrlresearchfutures) suggested that we should develop a "Research Immersion" program similar to those developed for other Association initiatives, including information literacy and scholarly communications. Others have noted the need to bring these opportunities to a broad audience through partnerships with ACRL Chapters and/or ACRL member libraries. Finally, some have noted the example of successful programs that might be sustained or scaled up through a strategic partnership with ACRL, e.g., the Institute for Research Design in Librarianship (http://irdlonline.org). IRDL is an IMLS-funded program bringing together the expertise housed in an LIS program (San Jose State University), a library consortium (SCELC, The Statewide California Electronic Library Consortium), an innovative academic library (Loyola Marymount University's William H. Hannon Library), and practicing librarians from across the U.S. and Canada serving as an advisory board. In the interest of full disclosure, I should note both that I am currently serving on the IRDL Advisory Board and that the need for a program like IRDL was suggested by the work that its founders published in this journal in 2012. ${ }^{1}$

But any program promoting research skills for academic librarians must also consider writing skills. Years ago, the now-defunct ACRL Research Program Committee piloted a "Research Writers Program" that offered one-on-one mentoring for new and experienced writers at ALA and ACRL conferences (including the National Conference in Philadelphia in 2011). Last month, I had the honor of taking part in the inaugural About Campus Writers Retreat, a program sponsored by that journal and the American College Personnel Association (ACPA) to provide similar (if more intensive) mentoring for new and experienced writers with an interest in writing for a broad-based higher education audience. Of the doctoral students, practicing student affairs professionals, and faculty members in Higher Education Administration who made up that cohort, I was the only librarian.

More information about the About Campus Writers Retreat is available at (http:// www.myacpa.org/article/announcing-inaugural-about-campus-writers-retreat-cohort) 
and I encourage $C \mathcal{E} R L$ readers to look for future calls for participation. Writing for a journal like About Campus is not the same as writing for College $\mathcal{E}$ Research Libraries, but the interest in this program (like the interest in the programs sponsored by the Research Program Committee) demonstrate the value of thinking about continuing professional education in writing alongside continuing professional education in research skills. Certainly, CERL peer reviewers and editorial board members consider the strength of both the research design and the writing style in considering which essays to publish in this journal.

As we conclude our celebration of the 75th anniversary of ACRL and College $\mathcal{E} R e-$ search Libraries, and as we welcome CERL's new editor-designate, Wendi Arant Kaspar, to the editorial board this month, I hope we will continue to think creatively about how the Association and its journals promote the continuing professional development of our members as both researchers and writers.

Scott Walter

DePaul University

\section{Notes}

1. Marie R. Kennedy and Kristine R. Brancolini, "Academic Librarian Research: A Survey of Attitudes, Involvement, and Perceived Capabilities," College \& Research Libraries 73 (2012): 431448, accessed June 16, 2015, doi: 10.5860/crl-276 